CRYSTALLOGRAPHIC COMMUNICATIONS

ISSN 2056-9890

\section{A cinnamaldehyde Schiff base of $S$-(4-methylbenz- yl) dithiocarbazate: crystal structure, Hirshfeld surface analysis and computational study}

\author{
Enis Nadia Md Yusof, ${ }^{a}$ Mohamed I. M. Tahir, ${ }^{a}$ Thahira B. S. A. Ravoof, ${ }^{a} \ddagger$ Sang Loon \\ $\operatorname{Tan}^{\mathrm{b}}$ and Edward R. T. Tiekink ${ }^{\mathrm{b} *}$
}

Received 10 March 2017

Accepted 13 March 2017

Edited by W. T. A. Harrison, University of Aberdeen, Scotland

₹ Additional correspondence author, e-mail: thahira@upm.edu.my.

Keywords: crystal structure; hydrogen bonding; dithiocarbazate ester; Hirshfeld surface analysis; DFT.

CCDC reference: 1537500

Supporting information: this article has supporting information at journals.iucr.org/e
(II)

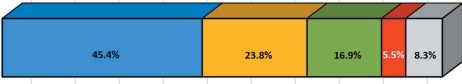

(I)

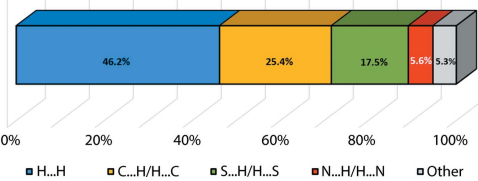

a Department of Chemistry, Faculty of Science, Universiti Putra Malaysia, 43400, UPM Serdang, Selangor Darul Ehsan, Malaysia, and ${ }^{\mathbf{b}}$ Research Centre for Crystalline Materials, School of Science and Technology, Sunway University, 47500 Bandar Sunway, Selangor Darul Ehsan, Malaysia. *Correspondence e-mail: edwardt@sunway.edu.my

The title dithiocarbazate ester (I), $\mathrm{C}_{18} \mathrm{H}_{18} \mathrm{~N}_{2} \mathrm{~S}_{2}$ [systematic name: (E)-4methylbenzyl 2-[(E)-3-phenylallylidene]hydrazinecarbodithioate, comprises an almost planar central $\mathrm{CN}_{2} \mathrm{~S}_{2}$ residue [r.m.s. deviation $=0.0131 \AA$ ]. The methylene(tolyl-4) group forms a dihedral angle of $72.25(4)^{\circ}$ with the best plane through the remaining non-hydrogen atoms [r.m.s. deviation $=0.0586 \AA$ ] so the molecule approximates mirror symmetry with the 4-tolyl group bisected by the plane. The configuration about both double bonds in the $\mathrm{N}-\mathrm{N}=\mathrm{C}-$ $\mathrm{C}=\mathrm{C}$ chain is $E$; the chain has an all trans conformation. In the crystal, eightmembered centrosymmetric thioamide synthons, $\{\cdots \mathrm{HNCS}\}_{2}$, are formed via $\mathrm{N}-\mathrm{H} \cdots \mathrm{S}$ (thione) hydrogen bonds. Connections between the dimers via $\mathrm{C}-$ $\mathrm{H} \cdots \pi$ interactions lead to a three-dimensional architecture. A Hirshfeld surface analysis shows that (I) possesses an interaction profile similar to that of a closely related analogue with an $S$-bound benzyl substituent, (II). Computational chemistry indicates the dimeric species of (II) connected via $\mathrm{N}-\mathrm{H} \cdots \mathrm{S}$ hydrogen bonds is about $0.94 \mathrm{kcal} \mathrm{mol}^{-1}$ more stable than that in (I).

\section{Chemical context}

A large number of studies have been carried out since 1974 on dithiocarbazate-derived Schiff bases of general formula $\mathrm{NH}_{2} \mathrm{NHC}(=\mathrm{S}) \mathrm{S} R$ which are synthesized from the condensation reaction of $S$-alkyl or -aryl esters of dithiocarbazic acid with different types of aldehydes or ketones (Ali \& Livingstone, 1974; Ravoof et al., 2010; Hamid et al., 2016). Recent work has reported electrochemical studies of conjugated copper(II) dithiocarbazate complexes that undergo an irreversible oxidation/reduction of $\mathrm{Cu}^{\mathrm{II}} / \mathrm{Cu}^{\mathrm{I}}$ (Blower et al., 2003; Paterson et al., 2010). Dithiocarbazate Schiff bases have also been reported to show variable cytotoxicity against estrogen receptor positive human breast cancer cells (MDA-MB-231) and other cell lines depending on their substituents (Pavan $e t$ al., 2010; Low et al., 2016). In fact, related 2-acetylpyridine Schiff bases of $S$-methyl- and $S$-benzyl-dithiocarbazate have better cytotoxic potential as compared to their complexes (Hamid et al., 2016). As part of an on-going study on the potential biological activities and structural chemistry of dithiocarbazate Schiff bases and their metal complexes (Yusof, Ravoof, Jamsari et al., 2015; Yusof, Ravoof, Tiekink et al., 2015; Low et al., 2016), the synthesis of the title compound, (I), its crystal and molecular structures along with an analysis of its Hirshfeld surface and computational modelling are reported herein. 


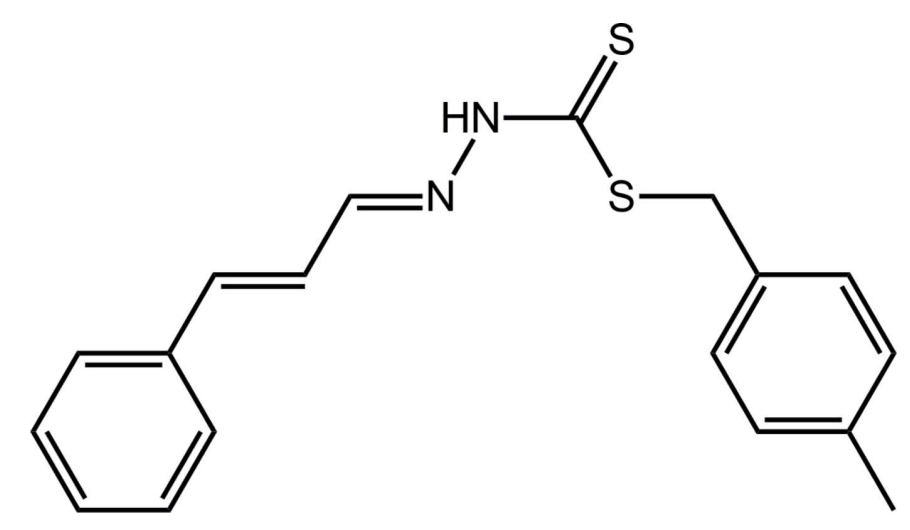

\section{Structural commentary}

The molecular structure of (I), Fig. 1, comprises three distinct residues with the central $\mathrm{CN}_{2} \mathrm{~S}_{2}$ group being essentially planar with an r.m.s. deviation of the fitted atoms being $0.0131 \AA$. Appended to this at the $\mathrm{S} 2$ atom is a $\mathrm{CH}_{2}$ (tolyl-4) residue [r.m.s. deviation $=0.0192 \AA$ ], and at $\mathrm{N} 2$, via a $\mathrm{C} 2=\mathrm{N} 2$ imine bond, is a $\mathrm{C}(\mathrm{H})-\mathrm{C}(\mathrm{H})=\mathrm{C}(\mathrm{H}) \mathrm{Ph}$ group [r.m.s. deviation = $0.0191 \AA]$. The dihedral angles between the central group and the S2- and N2-bound substituents are 71.65 (4) and $7.08(8)^{\circ}$, respectively. The dihedral angle between the outer groups is $72.33(4)^{\circ}$ and is indicative of an approximately orthogonal relationship. Indeed, the r.m.s. deviation of all non-hydrogen atom in (I) except those comprising the $\mathrm{CH}_{2}$ (tolyl-4) residue is $0.0586 \AA$, and the angle between this plane and that through the $\mathrm{CH}_{2}$ (tolyl-4) residue is 72.25 (4) ${ }^{\circ}$. The 1,4-carbon atoms of the 4-tolyl ring lie on the approximate mirror plane defined by the rest of the molecule with the remaining pairs of ring atoms being related across the putative plane.

The configuration about the $\mathrm{C} 2=\mathrm{N} 2$ imine $[1.284$ (2) $\AA$ ] and $\mathrm{C} 3=\mathrm{C} 4$ ethene $[1.339$ (2) $\AA$ ] bonds is $E$ in each case. This implies the $\mathrm{N} 1-\mathrm{N} 2=\mathrm{C} 2-\mathrm{C} 3=\mathrm{C} 4$ sequence has an all trans conformation as seen in the $\mathrm{N} 1-\mathrm{N} 2-\mathrm{C} 2-\mathrm{C} 3, \mathrm{~N} 2-\mathrm{C} 2-$ $\mathrm{C} 3-\mathrm{C} 4$ and $\mathrm{C} 2-\mathrm{C} 3-\mathrm{C} 4-\mathrm{C} 5$ torsion angles of 177.41 (13),

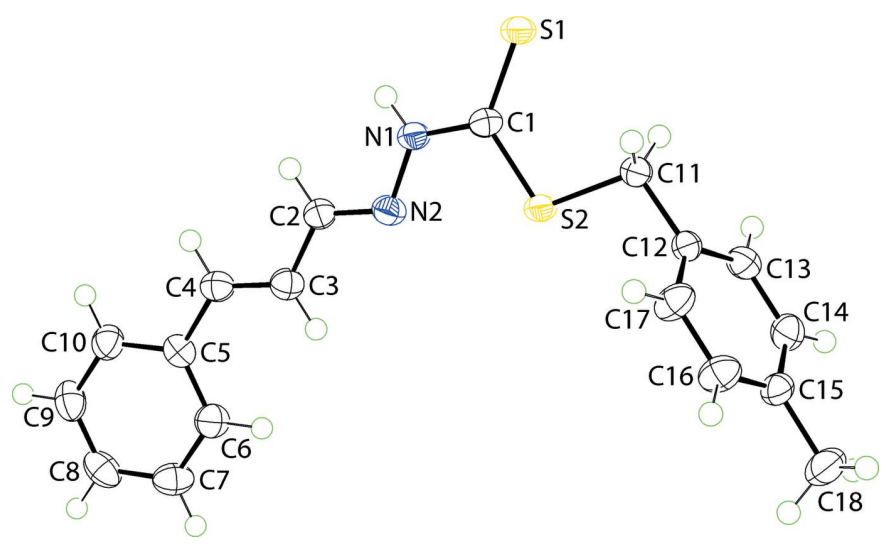

Figure 1

The molecular structure of (I) showing the atom-labelling scheme and displacement ellipsoids at the $70 \%$ probability level.
$-178.70(15)$ and $178.23(15)^{\circ}$, respectively. The $\mathrm{C} 1-\mathrm{S} 2$

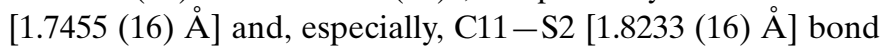
lengths are considerably longer than the $\mathrm{C} 1-\mathrm{S} 1$ bond [1.6752 (16) $\AA$ ] consistent with considerable thione character in the latter. This is borne out also by the observation that the angles about the $\mathrm{C} 1$ atom involving $\mathrm{S} 1$ are wider, by over $7^{\circ}$, i.e. $\mathrm{S} 1-\mathrm{C} 1-\mathrm{S} 2=125.20(10)^{\circ}$ and $\mathrm{N} 1-\mathrm{C} 1-\mathrm{S} 1121.06(12)^{\circ}$, cf. $\mathrm{N} 1-\mathrm{C} 1-\mathrm{S} 2$ of $113.74(11)^{\circ}$.

Further discussion on the molecular geometry of (I) is given in Computational chemistry calculations.

\section{Supramolecular features}

The most prominent feature of the molecular packing is the formation of an eight-membered, centrosymmetric thioamide synthon, $\quad\{\cdots \mathrm{HNCS}\}_{2}$ mediated by $\mathrm{N}-\mathrm{H} \cdots \mathrm{S}$ (thione) hydrogen bonds, Fig. $2 a$ and Table 1 . The dimeric aggregates thus formed are connected into a three-dimensional architecture, Fig. $2 b$, via methylene-C $-\mathrm{H} \cdots \pi$ (tolyl), tolyl-C$\mathrm{H} \cdots \pi$ (phenyl) and phenyl-C $-\mathrm{H} \cdots \pi$ (tolyl) interactions, Table 1, indicating the tolyl ring accepts two such contacts. In

(a)

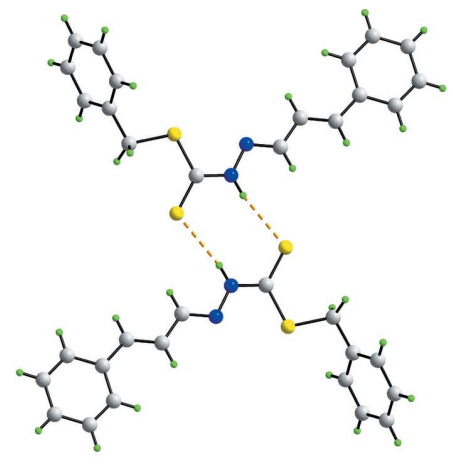

(b)

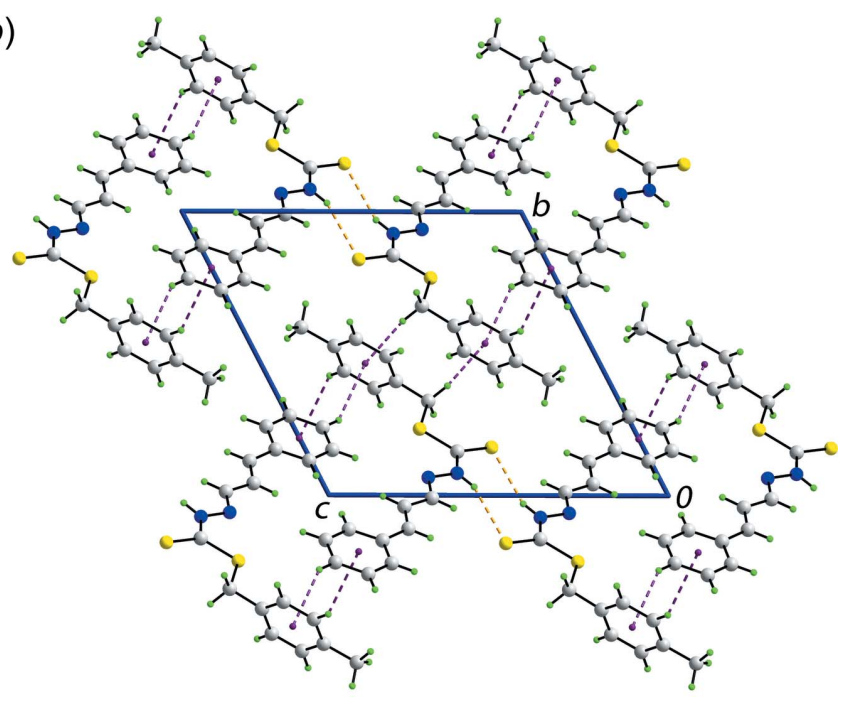

Figure 2

Molecular packing in (I): (a) a view of the supramolecular dimer sustained by $\mathrm{N}-\mathrm{H} \cdots \mathrm{S}$ (thione) hydrogen bonds and $(b)$ a view of the unit-cell contents shown in projection down the $a$ axis. The $\mathrm{N}-\mathrm{H} \cdots \mathrm{S}$ and $\mathrm{C}-\mathrm{H} \cdots \pi$ interactions are shown as orange and purple dashed lines, respectively. 
Table 1

Hydrogen-bond geometry $\left(\AA,^{\circ}\right)$.

$C g 1$ and $C g 2$ are the centroids of the $(\mathrm{C} 5-\mathrm{C} 10)$ and $(\mathrm{C} 12-\mathrm{C} 17)$ rings, respectively.

\begin{tabular}{lllll}
\hline$D-\mathrm{H} \cdots A$ & $D-\mathrm{H}$ & $\mathrm{H} \cdots A$ & $D \cdots A$ & $D-\mathrm{H} \cdots A$ \\
\hline $\mathrm{N} 1-\mathrm{H} 1 N \cdots \mathrm{S} 1^{\mathrm{i}}$ & $0.87(2)$ & $2.57(2)$ & $3.3984(17)$ & $158(2)$ \\
$\mathrm{C} 14-\mathrm{H} 14 \cdots C g 1^{\mathrm{ii}}$ & 0.95 & 2.95 & $3.6749(19)$ & 134 \\
$\mathrm{C} 8-\mathrm{H} 8 \cdots C g 2^{\mathrm{iii}}$ & 0.95 & 2.75 & $3.5571(19)$ & 143 \\
$\mathrm{C} 11-\mathrm{H} 11 B \cdots C g 2^{\text {iv }}$ & 0.99 & 2.78 & $3.5110(18)$ & 131 \\
\hline
\end{tabular}

Symmetry codes: (i) $\quad-x+1,-y+2,-z+1 ; \quad$ (ii) $\quad-x+1,-y+2,-z$; (iii) $-x,-y+2,-z ;$ (iv) $-x+2,-y+1,-z+1$.

essence, the $\mathrm{C}-\mathrm{H} \cdots \pi$ interactions connect molecules into layers in the $b c$ plane and these are linked by the $\mathrm{N}-\mathrm{H} \cdots \mathrm{S}$ hydrogen bonds.

\section{Analysis of the Hirshfeld surfaces}

The most closely related compound in the crystallographic literature is one with a benzyl substituent at the S2 atom (Tarafder et al., 2008) rather than a $\mathrm{CH}_{2}$ (tolyl-4) group, that might be regarded as the 'parent' compound, hereafter referred to as (II). While detailed discussion on the comparison of their molecular geometries and computational modelling are given in Computational chemistry calculations, the present section focuses upon the study of intermolecular interactions formed by (I) and (II) in their respective crystals by Hirshfeld surface analysis in accord with the method described recently (Yeo et al., 2016).

Both (I) and (II) exhibit closely related topological interactions as evidenced by the relative distribution of similar contacts, Fig. 3, computed based upon the mapping of the contact distances at specific points on their Hirshfeld surfaces (Spackman \& Jayatilaka, 2009). Among the interactions, $\mathrm{H} \cdot \mathrm{H}$ contacts constitute the most dominant contacts in (I) and (II) at approximately 46.2 and $45.4 \%$, respectively. This is followed by $\mathrm{C} \cdots \mathrm{H} / \mathrm{H} \cdots \mathrm{C}$ [ $\mathrm{ca} 25.4 \%$ for (I) and $23.8 \%$ for (II)], S $\cdots \mathrm{H} / \mathrm{H} \cdots \mathrm{S}[\mathrm{ca} 17.5$ and $16.9 \%$ ], N $\cdots \mathrm{H} / \mathrm{H} \cdots \mathrm{N}[\mathrm{ca} 5.6$

(II)

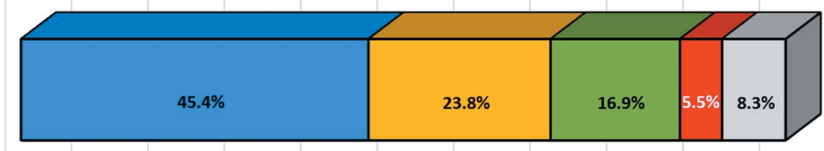

(I)

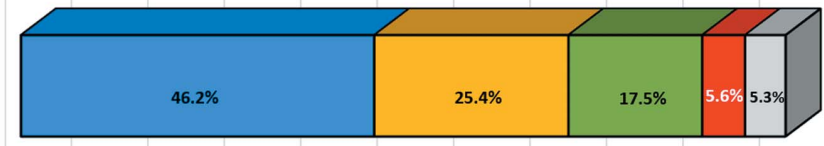

$0 \%$

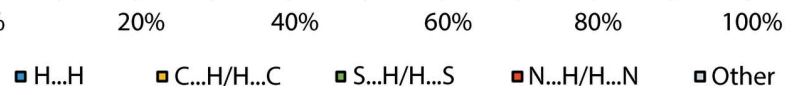

Figure 3

Relative percentage contributions of close contacts to the Hirshfeld surfaces of (I) and (II).
Table 2

Comparison of some physical properties between (I) and (II).

\begin{tabular}{lll}
\hline Property & $(\mathrm{I})$ & $(\mathrm{II})$ \\
\hline Volume, $V\left(\AA^{3}\right)$ & 416.41 & 384.29 \\
Surface area, $A\left(\AA^{2}\right)$ & 399.66 & 372.94 \\
$A: V$ & 0.96 & 0.97 \\
Density, $d\left(\mathrm{~g} \mathrm{~cm}^{-1}\right)$ & 1.274 & 1.320 \\
Kitaigorodskii Packing Index, KPI $(\%)$ & 67.5 & 68.5 \\
Globularity, $G$ & 0.675 & 0.685 \\
Asphericity, $\Omega$ & 0.326 & 0.359 \\
\hline
\end{tabular}

and $5.5 \%$ ] as well as other minor interactions including $\mathrm{N} \cdots \mathrm{C} /$ $\mathrm{C} \cdots \mathrm{N}, \mathrm{S} \cdots \mathrm{C} / \mathrm{C} \cdots \mathrm{S}$ and $\mathrm{S} \cdots \mathrm{N} / \mathrm{N} \cdots \mathrm{S}$, which constitute less than $5 \%$ of the overall contacts.

A detailed comparison of the two-dimensional fingerprint plots of $d_{\mathrm{i}} v s d_{\mathrm{e}}$ at the intervals of $0.01 \AA$ reveals that (I) and (II) are quantitatively different, despite both having a waspshape full fingerprint and similar Hirshfeld surface profiles, Fig. $4 a$,. Specifically, the decomposed fingerprint plot of $\mathrm{H} \cdots \mathrm{H}$ for (I) displays a $d_{\mathrm{e}}+d_{\mathrm{i}}$ contact distance of $1.96 \AA$ which is approximately $0.43 \AA$ (17\%) shorter $c f .2 .36 \AA$ for (II), Fig. $4 b$. Both (I) and (II) possess similar C..H/H..C contact distance, Fig. $4 c$, at approximately $2.7 \AA$, which is slightly shorter than the van der Waals radii of $2.9 \AA$. The decomposed fingerprint plots of $\mathrm{S} \cdots \mathrm{H} / \mathrm{H} \cdots \mathrm{S}$ (Fig. $4 d$ ) and $\mathrm{N} \cdots \mathrm{H} / \mathrm{H} \cdots \mathrm{N}$ contacts (Fig. 4e) for (I) register contact distances of 2.47 and $2.90 \AA$, respectively, which is about $0.05 \AA$ (1.7-2.0\%) longer than those of (II). It is noteworthy that the $\mathrm{H} \cdot \cdots \mathrm{H}$ contact of (I) is significantly shorter than the sum of their van der Waals radii, by $0.44 \AA(22.4 \%) c f$. (II), in which the difference is merely $0.04 \AA(1.7 \%)$. Similarly, the $\mathrm{S} \cdot \mathrm{H} / \mathrm{H}$ H. . S contacts of both (I) and (II) exhibit shorter contact distances $c f$. the sum of their van der Waals radii by 0.53 and $0.58 \AA$, respectively $(21.5$ and $24.0 \%)$. As a result, those contacts display intense red spots on their Hirshfeld surface, Fig. $4 d$.

In view of the close structural similarity between (I) and (II), their physical properties such as molecular volume, surface area, shape, density and packing efficiency were computed either by Crystal Explorer (Wolff et al., 2012) or PLATON (Spek, 2009) and data are compared in Table 2. As expected, the molecule of (I), which has an additional methyl group $c f$. (II), exhibits a greater molecular volume and surface area, and is slightly less globular. This results in a lower surface-to-volume ratio and density for (I), and ultimately leads to reduced packing efficiency when compared to (II).

\section{Database survey}

As mentioned in the previous section, the 'parent' compound represents the most closely related analogue to (I) in the Cambridge Crystallographic Database (Groom et al., 2016) and hence, it is adopted for direct comparison in terms of their geometric parameters; selected data are collated in Table 3. All bond lengths are equal within experimental error and bond angles agree to within $1^{\circ}$. The influence, if any, upon the molecular conformation exerted by the tolyl substituent in (I) might be manifested in the twists about the $\mathrm{C} 11-\mathrm{C} 12$ bond as 


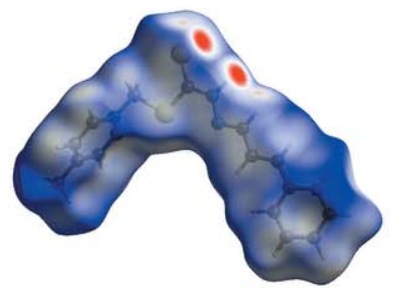

(a)

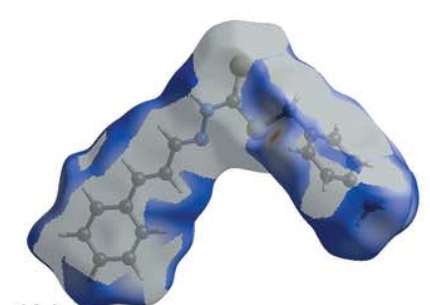

(b)

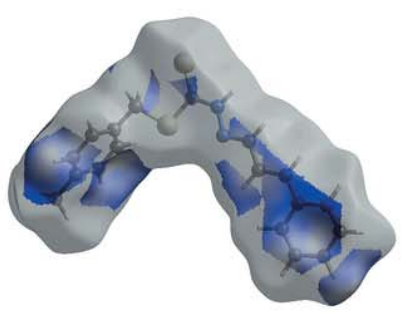

(c)

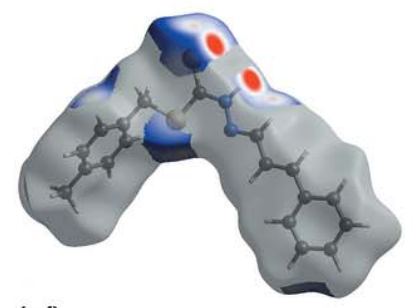

(d)
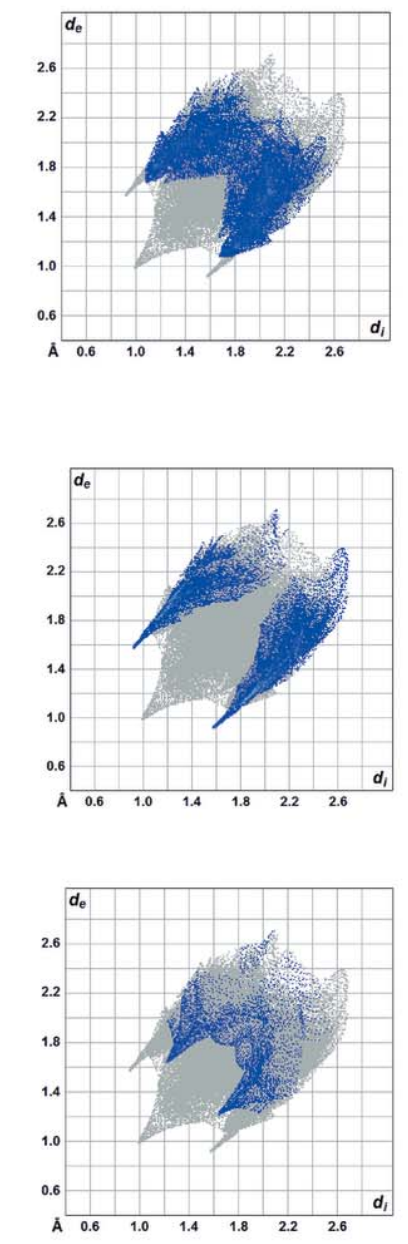

(I)
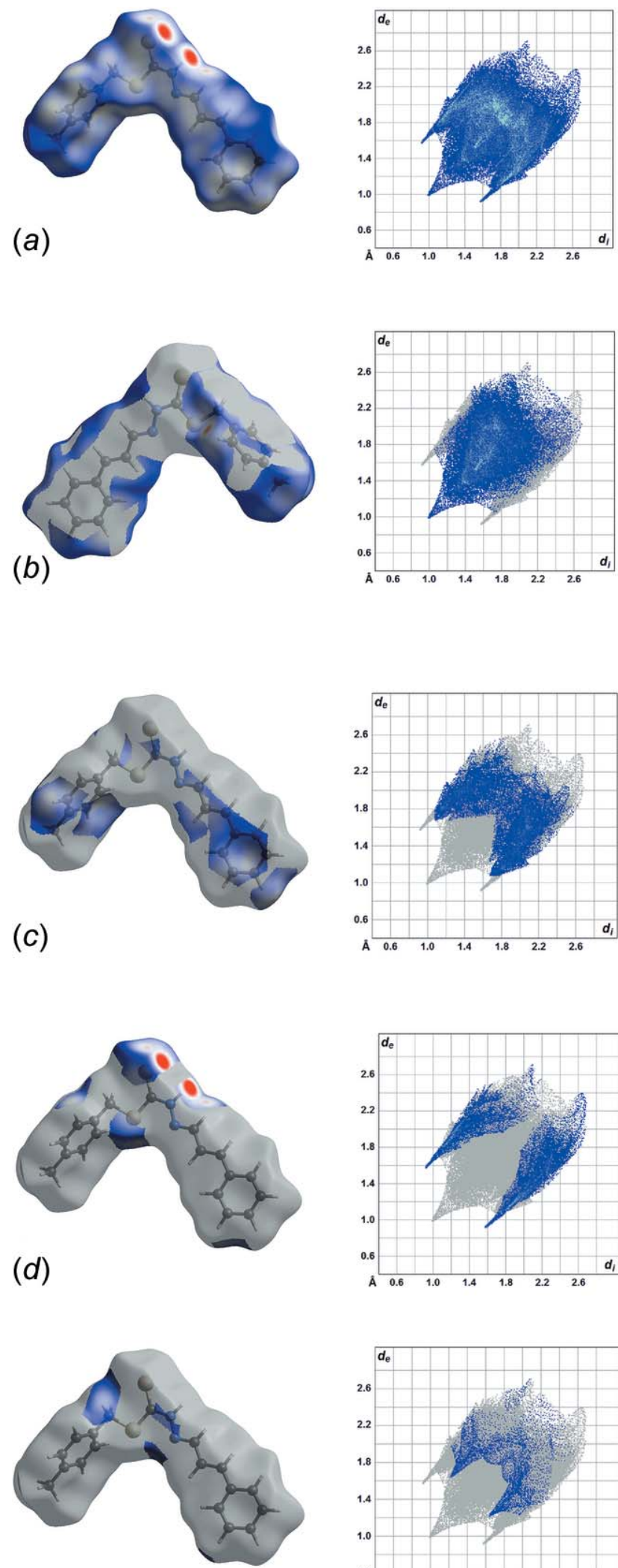

(e)
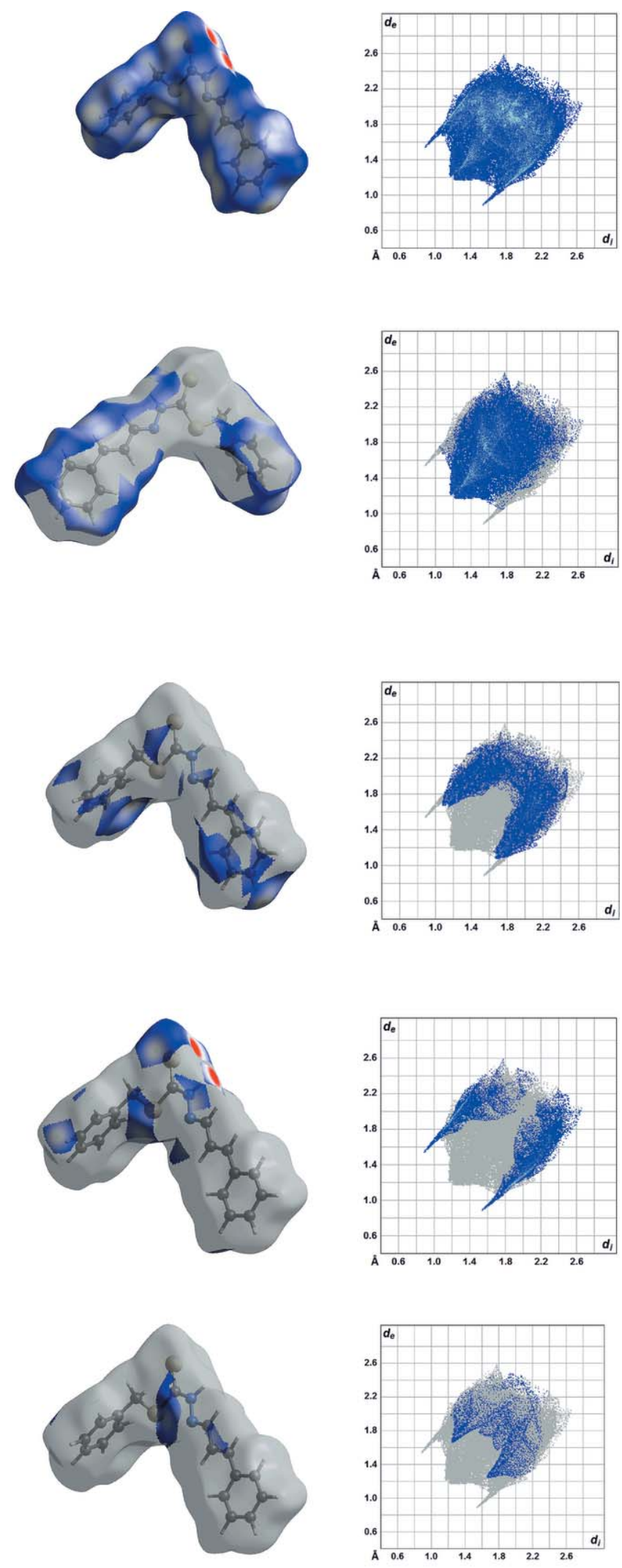

(II)

Figure 4

Fingerprint plots for (I) and (II): (a) overall and those delineated into $(b) \mathrm{H} \cdots \mathrm{H},(c) \mathrm{C} \cdots \mathrm{H} / \mathrm{H} \cdots \mathrm{C},(d) \mathrm{S} \cdots \mathrm{H} / \mathrm{H} \cdots \mathrm{S}$ and $(e) \mathrm{N} \cdots \mathrm{H} / \mathrm{H} \cdots \mathrm{N}$ contacts. Note that the Hirshfeld surface showing $\mathrm{H} \cdots \mathrm{H}$ contacts for (I) and (II) are illustrated in the reverse orientation so as to show the close contacts. 
Table 3

Selected geometric parameters $\left(\AA,^{\circ}\right)$ in (I) and (II) and in geometry-optimized-(I) and -(II).

\begin{tabular}{|c|c|c|c|c|}
\hline Parameter & (I) & (II) & optimized-(I) & optimized-(II) \\
\hline $\mathrm{C} 1-\mathrm{S} 1$ & $1.6752(16)$ & $1.670(2)$ & 1.665 & 1.665 \\
\hline $\mathrm{C} 1-\mathrm{S} 2$ & $1.7455(16)$ & $1.747(2)$ & 1.769 & 1.771 \\
\hline $\mathrm{C} 11-\mathrm{S} 2$ & $1.8233(16)$ & $1.8189(17)$ & 1.850 & 1.850 \\
\hline $\mathrm{N} 1-\mathrm{N} 2$ & $1.3845(18)$ & $1.382(2)$ & 1.354 & 1.353 \\
\hline $\mathrm{C} 2-\mathrm{N} 2$ & $1.284(2)$ & $1.285(2)$ & 1.288 & 1.290 \\
\hline $\mathrm{C} 2-\mathrm{C} 3$ & $1.435(2)$ & $1.433(3)$ & 1.439 & 1.439 \\
\hline $\mathrm{C} 3-\mathrm{C} 4$ & $1.339(2)$ & $1.337(2)$ & 1.350 & 1.350 \\
\hline $\mathrm{C} 1-\mathrm{N} 1-\mathrm{N} 2$ & $120.95(13)$ & $120.48(15)$ & 122.8 & 122.8 \\
\hline $\mathrm{N} 1-\mathrm{N} 2-\mathrm{C} 2$ & 114.17 (13) & $114.00(15)$ & 117.2 & 117.2 \\
\hline $\mathrm{S} 1-\mathrm{C} 1-\mathrm{S} 2$ & $125.20(10)$ & $124.67(11)$ & 127.0 & 127.0 \\
\hline $\mathrm{S} 1-\mathrm{C} 1-\mathrm{N} 1$ & $121.06(12)$ & $121.57(13)$ & 119.8 & 119.9 \\
\hline $\mathrm{S} 2-\mathrm{C} 1-\mathrm{N} 1$ & 113.74 (11) & 113.77 (14) & 113.2 & 113.1 \\
\hline $\mathrm{C} 2-\mathrm{C} 3-\mathrm{C} 4$ & $121.28(15)$ & $121.03(16)$ & 122.6 & 122.6 \\
\hline $\mathrm{C} 3-\mathrm{C} 4-\mathrm{C} 5$ & $127.33(16)$ & $128.25(16)$ & 127.5 & 127.5 \\
\hline $\mathrm{C} 3-\mathrm{C} 4-\mathrm{C} 5-\mathrm{C} 10$ & $178.69(16)$ & $173.64(19)$ & 178.0 & -178.8 \\
\hline
\end{tabular}

the $\mathrm{S} 2-\mathrm{C} 11-\mathrm{C} 12-\mathrm{C} 13$ torsion angles vary between $3-6^{\circ}$. Equivalent twists are also noted about the C5-C6 bond.

\section{Computational chemistry calculations}

Both (I) and (II) were subjected to geometry optimization calculations assuming a gas-phase environment in order to compare the structural difference between the experimental and theoretical models. The corresponding theoretical models were first drawn using GaussView5 (Dennington et al., 2009) based on the geometrical conformation of the structure (trans-cis along $\mathrm{C} 1=\mathrm{S} 1$ and $E, E$ along $\mathrm{N} 2-\mathrm{C} 2, \mathrm{C} 3-\mathrm{C} 4)$ and pre-optimized using a semi empirical method (PM6) with a precise self-consistent field criterion. Subsequently, the geometries were further optimized at B3LYP/6-311+G $(d, p)$ without imposing symmetry constraints. A frequency analysis was performed on each optimized structure using the same level of theory and basis set to validate that each structure was indeed the local minimum structure with no imaginary

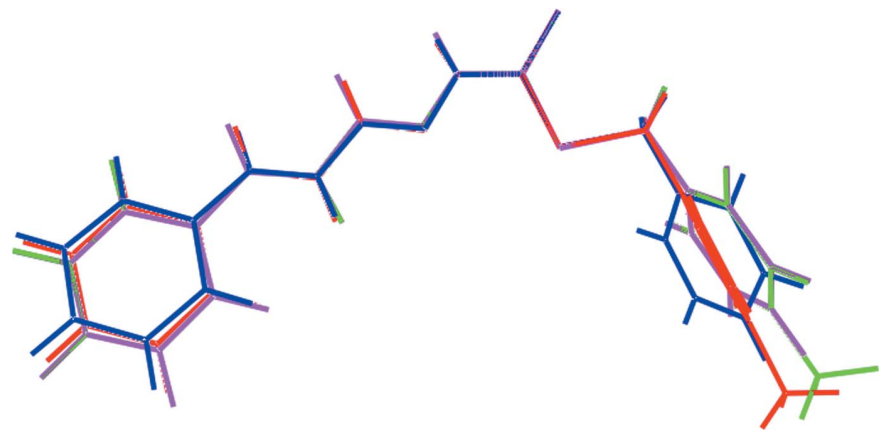

Figure 5

Structural overlay between the crystal and optimized structures of (I) (red image), (Io) (green), (II) blue) and (IIo) (purple). frequency. All calculations were performed using the Gaussian09 software package (Frisch et al., 2016).

The results, as shown from the superposition of the experimental structure and theoretical model of (I) and (II), Fig. 5, indicate that there is not much difference between the experimental and optimized structures with the r.m.s. deviation of about $0.2110 \AA$ in the case of (I) and $0.1747 \AA$ in the case of (II). The key geometric parameters obtained from the calculations are also listed in Table 3. The energy-minimized structures have effective mirror symmetry whereby the Sbound aryl ring is bisected by the plane. The bond lengths and angles for optimized-(I) and -(II) are identical indicating no influence upon the electronic structure is exerted by the addition of a methyl group in (I). Indeed, the optimized geometries for (I) and (II) are superimposable, Fig. 5. Despite the close similarity between the optimized structures, some differences are noted between the experimental and optimized structures. For example, the $\mathrm{C} 1-\mathrm{S} 2$ and $\mathrm{C} 11-\mathrm{S} 2$ bond lengths have elongated by $c a 0.02$ and $0.03 \AA$, respectively. In the chain, the $\mathrm{C} 1-\mathrm{N} 1$ bond lengths have lengthened by $c a$ $0.03 \AA$, a difference accompanied by a contraction in the $\mathrm{N} 1-$ N2 bond length by about the same amount. Minor differences are also noted in bond angles with widening of $\mathrm{S} 1-\mathrm{C} 1-\mathrm{S} 2$ and the angles subtended at the nitrogen atoms by $2-3^{\circ}$ with similar contractions in the $\mathrm{C} 1-\mathrm{S} 1-\mathrm{C} 11$ and $\mathrm{S} 1-\mathrm{C} 1-\mathrm{N} 1$ angles.

Apart from geometry optimization, both (I) and (II) were also subjected to computational modelling for calculation of their interaction energies. Briefly, the crystallographic coordinates of the experimental dimeric structures of (I) and (II) connected through $\mathrm{N}-\mathrm{H} \cdots \mathrm{S}$ interactions were used as the input without further optimization. In order to preserve the integrity of the structure for best possible estimation of the interaction energy from the experimental model, the positions 
of all hydrogen atoms obtained during crystal refinement were kept unchanged, despite that this method (riding-model approximation) is commonly known to induce deviations by as much as 0.1 to $0.2 \AA$ shorter $\mathrm{C}-\mathrm{H}$ bond lengths. The respective input structures were submitted to single point interaction energy calculation by long-range corrected $\omega \mathrm{B} 97 \mathrm{XD}$ functional combining the $\mathrm{D} 2$ version of Grimme's dispersion model and the $6-31 \mathrm{G}(d, p)$ basis set. It has been demonstrated that the long-range corrected hybrid method can greatly reduce self-interaction errors (Chai \& HeadGordon, 2008) and gives a better accuracy in binding energy as compared to coupled cluster calculations (Andersen et al., 2014). The computed interaction energy (i.e. the energy difference between the dimer and the sum of energies for the corresponding monomers) was obtained upon the correction of basis set superposition error (BSSE) by counterpoise correction. All calculations were performed in gas phase using Gaussian09 software (Frisch et al., 2016).

The dimeric species of (I) and (II) possesses the interaction energy $\left(E_{\text {int }}^{\mathrm{BSSE}}\right)$ of -12.92 and $-13.86 \mathrm{kcal} \mathrm{mol}^{-1}$, respectively. The range is approximately 3.89 to $5.23 \mathrm{kcal} \mathrm{mol}^{-1}$ less than the energy computed for a pair of thiourea dimers at the RIMP2/cc-pVDZ and cc-pVTZ levels of theory (AIDamen \& Sinnokrot, 2014). Apparently, the corresponding $E^{\mathrm{BSSE}}$ energies were overestimated due to the use of the splitvalence double basis set as an necessary compromise between accuracy and computational cost since the calculations involve a rather large molecular system with over 80 atoms. Despite the difference, the dimer of (II) is lower in energy ( $c a 0.94 \mathrm{kcal}$ $\mathrm{mol}^{-1}$ ) $c f$. (I), indicating that the former is connected by relatively stronger $\mathrm{N}-\mathrm{H} \cdots \mathrm{S}$ interactions and hence, the dimeric aggregate in (II) is more stable. The theoretical result is in accord with the experimental data, in which the $\mathrm{H} \cdots \mathrm{S}$ [2.53(2) $\AA$ ] and N...S [3.3714(19) $\AA$ ] bond lengths are shorter and the $\mathrm{N}-\mathrm{H} \cdots \mathrm{S}\left[165(2)^{\circ}\right]$ bond angle is wider in (II) $c f .(\mathrm{I})$, Table 1.

\section{Synthesis and crystallization}

The following procedure was adapted from the literature (Ravoof et al., 2010): S-4-methylbenzyldithiocarbazate (2.12 g, $0.01 \mathrm{~mol})$ was dissolved in hot acetonitrile $(100 \mathrm{ml})$ and added to an equimolar amount of cinnamaldehyde (Merck, $1.32 \mathrm{~g}$ ) in absolute ethanol $(20 \mathrm{ml})$. The mixture was heated for about $2 \mathrm{~h}$ and was then allowed to stand overnight. The pale-brown crystals that formed were filtered and washed with absolute ethanol at room temperature. Yield: 70\%. M.p. 463-466 K. Analysis: Calculated for $\mathrm{C}_{18} \mathrm{H}_{18} \mathrm{~N}_{2} \mathrm{~S}_{2}$ : C, 66.22; H, 5.56; N, 8.58. Found: C, 65.87; H, 5.77; N, 9.00\%. FT-IR (ATR, $\left.\mathrm{cm}^{-1}\right)$ : 3102, $v(\mathrm{~N}-\mathrm{H}) ; 1613, v(\mathrm{C}=\mathrm{N}) ; 1021, v(\mathrm{~N}-\mathrm{N}) ; 749, v(\mathrm{CSS})$.

\section{Refinement}

Crystal data, data collection and structure refinement details are summarized in Table 4. The carbon-bound $\mathrm{H}$ atoms were placed in calculated positions $(\mathrm{C}-\mathrm{H}=0.95-0.99 \AA)$ and were included in the refinement in the riding-model approximation,
Table 4

Experimental details.

\begin{tabular}{|c|c|}
\hline \multicolumn{2}{|l|}{ Crystal data } \\
\hline Chemical formula & $\mathrm{C}_{18} \mathrm{H}_{18} \mathrm{~N}_{2} \mathrm{~S}_{2}$ \\
\hline$M_{\mathrm{r}}$ & 326.46 \\
\hline Crystal system, space group & Triclinic, $P \overline{1}$ \\
\hline Temperature (K) & 100 \\
\hline$a, b, c(\AA)$ & $5.6720(3), 12.6288(7), 13.4690(8)$ \\
\hline$\alpha, \beta, \gamma\left({ }^{\circ}\right)$ & $62.451(6), 84.441(5), 88.930(5)$ \\
\hline$V\left(\AA^{3}\right)$ & $851.00(9)$ \\
\hline$Z$ & 2 \\
\hline Radiation type & $\mathrm{Cu} K \alpha$ \\
\hline$\mu\left(\mathrm{mm}^{-1}\right)$ & 2.80 \\
\hline Crystal size $(\mathrm{mm})$ & $0.19 \times 0.18 \times 0.08$ \\
\hline \multicolumn{2}{|l|}{ Data collection } \\
\hline Diffractometer & Agilent Xcalibur, Eos, Gemini \\
\hline Absorption correction & $\begin{array}{l}\text { Multi-scan CrysAlis PRO (Agilent, } \\
\text { 2011) }\end{array}$ \\
\hline$T_{\min }, T_{\max }$ & $0.802,1.000$ \\
\hline $\begin{array}{l}\text { No. of measured, independent and } \\
\text { observed }[I>2 \sigma(I)] \text { reflections }\end{array}$ & $11378,3272,2922$ \\
\hline$R_{\text {int }}$ & 0.025 \\
\hline$(\sin \theta / \lambda)_{\max }\left(\AA^{-1}\right)$ & 0.614 \\
\hline \multicolumn{2}{|l|}{ Refinement } \\
\hline$R\left[F^{2}>2 \sigma\left(F^{2}\right)\right], w R\left(F^{2}\right), S$ & $0.036,0.098,1.03$ \\
\hline No. of reflections & 3272 \\
\hline No. of parameters & 203 \\
\hline No. of restraints & 1 \\
\hline $\mathrm{H}$-atom treatment & $\begin{array}{l}\mathrm{H} \text { atoms treated by a mixture of } \\
\text { independent and constrained } \\
\text { refinement }\end{array}$ \\
\hline$\Delta \rho_{\max }, \Delta \rho_{\min }\left(\mathrm{e} \AA^{-3}\right)$ & $0.38,-0.21$ \\
\hline
\end{tabular}

Computer programs: CrysAlis (Agilent, 2011), SHELXS97 (Sheldrick, 2008), SHELXL2014/7 (Sheldrick, 2015), ORTEP-3 for Windows (Farrugia, 2012), DIAMOND (Brandenburg, 2006) and publCIF (Westrip, 2010).

with $U_{\text {iso }}(\mathrm{H})$ set to $1.2-1.5 U_{\text {eq }}(\mathrm{C})$. The nitrogen-bound $\mathrm{H}$ atom was located in a difference-Fourier map but was refined with a distance restraint of $\mathrm{N}-\mathrm{H}=0.88 \pm 0.01 \AA$, and with $U_{\text {iso }}(\mathrm{H})$ set to $1.2 U_{\text {eq }}(\mathrm{N})$.

\section{Acknowledgements}

We thank the Department of Chemistry (Universiti Putra Malaysia; UPM) for access to facilities. This research was funded by UPM and the Malaysian Government under the Malaysian Fundamental Research Grant Scheme (FRGS No. 01-01-16-1833FR) and Geran Penyelidikan-Inisiatif Putra Siswazah (GP-IPS No. 9504600). ENMY also wishes to acknowledge the MyPhD Malaysian Government Scholarship (MyBrain15). The authors are also grateful to Sunway University (INT-RRO-2017-096) for supporting this research.

\section{Funding information}

Funding for this research was provided by: Malaysian Fundamental Research Grant Scheme (award No. 01-01-161833FR); Geran Penyelidikan-Inisiatif Putra Siswazah (award No. 9504600); Sunway University (award No. INT-RRO-2017096). 


\section{References}

Agilent (2011). CrysAlis PRO. Agilent Technologies, Yarnton, England.

Ali, M. A. \& Livingstone, S. E. (1974). Coord. Chem. Rev. 13, 101132.

AlDamen, M. A. \& Sinnokrot, M. (2014). J. Struct. Chem. 55, 5360.

Andersen, C. L., Jensen, C. S., Mackeprang, K., Du, L., Jørgensen, S. \& Kjaergaard, H. G. (2014). J. Phys. Chem. A, 118, 11074-11082.

Blower, P. J., Castle, T. C., Cowley, A. R., Dilworth, J. R., Donnelly, P. S., Labisbal, E., Sowrey, F. E., Teat, S. J. \& Went, M. J. (2003). Dalton Trans. pp. 4416-4425.

Brandenburg, K. (2006). DIAMOND. Crystal Impact GbR, Bonn, Germany.

Chai, J. D. \& Head-Gordon, M. (2008). Phys. Chem. Chem. Phys. 10, 6615-6620.

Dennington, R., Keith, T. \& Millam, J. (2009). GaussView, Semichem Inc., Shawnee Mission KS.

Farrugia, L. J. (2012). J. Appl. Cryst. 45, 849-854.

Frisch, M. J., et al. (2016). Gaussian 09, Revision E. 01. Gaussian, Inc., Wallingford CT, USA.

Groom, C. R., Bruno, I. J., Lightfoot, M. P. \& Ward, S. C. (2016). Acta Cryst. B72, 171-179.

Hamid, M. H. S., Said, A. N. A., Mirza, A. H., Karim, M. R., Arifuzzaman, M., Ali, M. A. \& Bernhardt, P. V. (2016). Inorg. Chim. Acta, 453, 742-750.
Low, M. L., Maigre, L., Tahir, M. I. M., Tiekink, E. R. T., Dorlet, P., Guillot, R., Ravoof, T. B., Rosli, R., Pagès, J. M., Policar, C., Delsuc, N. \& Crouse, K. A. (2016). Eur. J. Med. Chem. 120, 1-12.

Yusof, E. N. Md., Ravoof, T. B. S. A., Tiekink, E. R. T., Veerakumarasivam, A., Crouse, K. A., Mohamed Tahir, M. I. \& Ahmad, H. (2015). Int. J. Mol. Sci. 16, 11034-11054.

Paterson, B. M., Karas, J. A., Scanlon, D. B., White, J. M. \& Donnelly, P. S. (2010). Inorg. Chem. 49, 1884-1893.

Pavan, F. R., Maia, P. I. da S., Leite, S. R., Deflon, V. M., Batista, A. A., Sato, D. N., Franzblau, S. G. \& Leite, C. Q. (2010). Eur. J. Med. Chem. 45, 1898-1905.

Ravoof, T. B. S. A., Crouse, K. A., Tahir, M. I. M., How, F. N. F., Rosli, R. \& Watkins, D. J. (2010). Transition Met. Chem. 35, 871-876.

Sheldrick, G. M. (2008). Acta Cryst. A64, 112-122.

Sheldrick, G. M. (2015). Acta Cryst. C71, 3-8.

Spackman, M. A. \& Jayatilaka, D. (2009). CrystEngComm, 11, 19-32. Spek, A. L. (2009). Acta Cryst. D65, 148-155.

Tarafder, M. T. H., Crouse, K. A., Islam, M. T., Chantrapromma, S. \& Fun, H.-K. (2008). Acta Cryst. E64, o1042-o1043.

Westrip, S. P. (2010). J. Appl. Cryst. 43, 920-925.

Wolff, S. K., Grimwood, D. J., McKinnon, J. J., Turner, M. J., Jayatilaka, D. \& Spackman, M. A. (2012). Crystal Explorer, version 3.1, University of Western Australia, Crawley.

Yeo, C. I., Tan, S. L., Otero-de-la-Roza, A. \& Tiekink, E. R. T. (2016). Z. Kristallogr. 231, 653-661.

Yusof, E. N. M., Ravoof, T. B. S. A., Jamsari, J., Tiekink, E. R. T., Veerakumarasivam, A., Crouse, K. A., Tahir, M. I. M. \& Ahmad, H. (2015). Inorg. Chim. Acta, 438, 85-93. 


\section{supporting information}

Acta Cryst. (2017). E73, 543-549 [https://doi.org/10.1107/S2056989017003991]

\section{A cinnamaldehyde Schiff base of S-(4-methylbenzyl) dithiocarbazate: crystal structure, Hirshfeld surface analysis and computational study}

Enis Nadia Md Yusof, Mohamed I. M. Tahir, Thahira B. S. A. Ravoof, Sang Loon Tan and Edward

\section{R. T. Tiekink}

Computing details

Data collection: CrysAlis (Agilent, 2011); cell refinement: CrysAlis (Agilent, 2011); data reduction: CrysAlis (Agilent, 2011); program(s) used to solve structure: SHELXS97 (Sheldrick, 2008); program(s) used to refine structure: SHELXL2014/7 (Sheldrick, 2015); molecular graphics: ORTEP-3 for Windows (Farrugia, 2012), DIAMOND (Brandenburg, 2006); software used to prepare material for publication: publCIF (Westrip, 2010).

(E)-4-Methylbenzyl 2-[(E)-3-phenylallylidene]hydrazinecarbodithioate

Crystal data

$\mathrm{C}_{18} \mathrm{H}_{18} \mathrm{~N}_{2} \mathrm{~S}_{2}$

$M_{r}=326.46$

Triclinic, $P \overline{1}$

$a=5.6720(3) \AA$

$b=12.6288(7) \AA$

$c=13.4690(8) \AA$

$\alpha=62.451(6)^{\circ}$

$\beta=84.441(5)^{\circ}$

$\gamma=88.930(5)^{\circ}$

$V=851.00(9) \AA^{3}$

\section{Data collection}

Agilent Xcalibur, Eos, Gemini diffractometer

Radiation source: Enhance $(\mathrm{Cu}) \mathrm{X}$-ray Source Graphite monochromator

Detector resolution: 16.1952 pixels $\mathrm{mm}^{-1}$

$\omega$ scans

Absorption correction: multi-scan

CrysAlisPro (Agilent, 2011)

$T_{\text {min }}=0.802, T_{\text {max }}=1.000$

Refinement

Refinement on $F^{2}$

Least-squares matrix: full

$R\left[F^{2}>2 \sigma\left(F^{2}\right)\right]=0.036$

$w R\left(F^{2}\right)=0.098$

$S=1.03$

3272 reflections
$Z=2$

$F(000)=344$

$D_{\mathrm{x}}=1.274 \mathrm{Mg} \mathrm{m}^{-3}$

$\mathrm{Cu} K \alpha$ radiation, $\lambda=1.5418 \AA$

Cell parameters from 5602 reflections

$\theta=3.7-71.2^{\circ}$

$\mu=2.80 \mathrm{~mm}^{-1}$

$T=100 \mathrm{~K}$

Prism, light-brown

$0.19 \times 0.18 \times 0.08 \mathrm{~mm}$

11378 measured reflections

3272 independent reflections

2922 reflections with $I>2 \sigma(I)$

$R_{\text {int }}=0.025$

$\theta_{\text {max }}=71.3^{\circ}, \theta_{\min }=3.7^{\circ}$

$h=-6 \rightarrow 6$

$k=-15 \rightarrow 15$

$l=-16 \rightarrow 16$ 
$(\Delta / \sigma)_{\max }<0.001$

$\Delta \rho_{\max }=0.38$ e $\AA^{-3}$

$$
\Delta \rho_{\min }=-0.21 \text { e } \AA^{-3}
$$

Special details

Geometry. All esds (except the esd in the dihedral angle between two 1.s. planes) are estimated using the full covariance matrix. The cell esds are taken into account individually in the estimation of esds in distances, angles and torsion angles; correlations between esds in cell parameters are only used when they are defined by crystal symmetry. An approximate (isotropic) treatment of cell esds is used for estimating esds involving l.s. planes.

Fractional atomic coordinates and isotropic or equivalent isotropic displacement parameters $\left(\AA^{2}\right)$

\begin{tabular}{|c|c|c|c|c|}
\hline & $x$ & $y$ & $z$ & $U_{\text {iso }} * / U_{\text {eq }}$ \\
\hline S1 & $0.70595(7)$ & $0.83091(3)$ & $0.55216(3)$ & $0.02412(13)$ \\
\hline S2 & $0.61163(7)$ & $0.76634(3)$ & $0.36831(3)$ & $0.02024(13)$ \\
\hline N1 & $0.3820(2)$ & $0.92216(12)$ & $0.41092(11)$ & $0.0213(3)$ \\
\hline $\mathrm{H} 1 \mathrm{~N}$ & $0.356(3)$ & $0.9703(15)$ & $0.4406(15)$ & $0.026^{*}$ \\
\hline $\mathrm{N} 2$ & $0.2657(2)$ & $0.93744(12)$ & $0.31965(11)$ & $0.0218(3)$ \\
\hline $\mathrm{C} 1$ & $0.5581(3)$ & $0.84581(13)$ & $0.44483(13)$ & $0.0194(3)$ \\
\hline $\mathrm{C} 2$ & $0.0948(3)$ & $1.01051(14)$ & $0.29902(13)$ & $0.0211(3)$ \\
\hline $\mathrm{H} 2$ & 0.0558 & 1.0455 & 0.3474 & $0.025 *$ \\
\hline $\mathrm{C} 3$ & $-0.0385(3)$ & $1.04062(14)$ & $0.20473(14)$ & $0.0225(3)$ \\
\hline H3 & -0.0020 & 1.0045 & 0.1572 & $0.027^{*}$ \\
\hline $\mathrm{C} 4$ & $-0.2135(3)$ & $1.11863(14)$ & $0.18249(14)$ & $0.0226(3)$ \\
\hline $\mathrm{H} 4$ & -0.2465 & 1.1506 & 0.2336 & $0.027 *$ \\
\hline $\mathrm{C} 5$ & $-0.3594(3)$ & $1.16011(14)$ & $0.08835(13)$ & $0.0213(3)$ \\
\hline C6 & $-0.3306(3)$ & $1.12110(15)$ & 0.00607 (14) & $0.0257(4)$ \\
\hline H6 & -0.2076 & 1.0681 & 0.0085 & $0.031^{*}$ \\
\hline $\mathrm{C} 7$ & $-0.4800(3)$ & $1.15911(15)$ & $-0.07886(14)$ & $0.0286(4)$ \\
\hline $\mathrm{H} 7$ & -0.4600 & 1.1311 & -0.1335 & $0.034^{*}$ \\
\hline $\mathrm{C} 8$ & $-0.6589(3)$ & $1.23796(16)$ & $-0.08460(14)$ & $0.0287(4)$ \\
\hline $\mathrm{H} 8$ & -0.7615 & 1.2635 & -0.1427 & $0.034^{*}$ \\
\hline C9 & $-0.6863(3)$ & $1.27894(16)$ & $-0.00499(15)$ & $0.0294(4)$ \\
\hline H9 & -0.8071 & 1.3335 & -0.0090 & $0.035^{*}$ \\
\hline $\mathrm{C} 10$ & $-0.5382(3)$ & $1.24059(16)$ & $0.08037(14)$ & $0.0262(4)$ \\
\hline H10 & -0.5584 & 1.2695 & 0.1344 & $0.031^{*}$ \\
\hline C11 & $0.8493(3)$ & $0.66793(14)$ & $0.43635(13)$ & $0.0209(3)$ \\
\hline H11A & 0.9914 & 0.7149 & 0.4318 & $0.025^{*}$ \\
\hline H11B & 0.7981 & 0.6139 & 0.5165 & $0.025^{*}$ \\
\hline $\mathrm{C} 12$ & $0.9009(3)$ & $0.59760(13)$ & $0.37170(13)$ & $0.0186(3)$ \\
\hline $\mathrm{C} 13$ & $1.1047(3)$ & $0.62246(15)$ & $0.29770(14)$ & $0.0233(3)$ \\
\hline H13 & 1.2160 & 0.6817 & 0.2901 & $0.028^{*}$ \\
\hline C14 & $1.1471(3)$ & $0.56131(16)$ & $0.23458(14)$ & $0.0260(4)$ \\
\hline H14 & 1.2876 & 0.5793 & 0.1845 & $0.031^{*}$ \\
\hline $\mathrm{C} 15$ & $0.9884(3)$ & $0.47474(14)$ & $0.24348(13)$ & $0.0226(3)$ \\
\hline $\mathrm{C} 16$ & $0.7849(3)$ & $0.44935(15)$ & $0.31824(15)$ & $0.0274(4)$ \\
\hline H16 & 0.6740 & 0.3898 & 0.3261 & $0.033^{*}$ \\
\hline C17 & $0.7425(3)$ & $0.50994(15)$ & $0.38120(15)$ & $0.0267(4)$ \\
\hline H17 & 0.6026 & 0.4913 & 0.4318 & $0.032 *$ \\
\hline $\mathrm{C} 18$ & $1.0331(4)$ & $0.40915(17)$ & $0.17430(16)$ & $0.0326(4)$ \\
\hline
\end{tabular}


supporting information

\begin{tabular}{lllll}
$\mathrm{H} 18 \mathrm{~A}$ & 1.1663 & 0.4481 & 0.1168 & $0.049^{*}$ \\
$\mathrm{H} 18 \mathrm{~B}$ & 0.8910 & 0.4107 & 0.1377 & $0.049^{*}$ \\
$\mathrm{H} 18 \mathrm{C}$ & 1.0709 & 0.3261 & 0.2234 & $0.049^{*}$ \\
\hline
\end{tabular}

Atomic displacement parameters $\left(\AA^{2}\right)$

\begin{tabular}{lllllll}
\hline & $U^{11}$ & $U^{22}$ & $U^{33}$ & $U^{12}$ & $U^{13}$ & $U^{23}$ \\
\hline S1 & $0.0306(2)$ & $0.0249(2)$ & $0.0242(2)$ & $0.00799(17)$ & $-0.01188(17)$ & $-0.01611(17)$ \\
S2 & $0.0252(2)$ & $0.0196(2)$ & $0.0208(2)$ & $0.00461(15)$ & $-0.00790(15)$ & $-0.01252(16)$ \\
N1 & $0.0254(7)$ & $0.0217(7)$ & $0.0226(7)$ & $0.0054(6)$ & $-0.0082(5)$ & $-0.0141(6)$ \\
N2 & $0.0242(7)$ & $0.0220(7)$ & $0.0204(7)$ & $0.0018(6)$ & $-0.0062(5)$ & $-0.0101(5)$ \\
C1 & $0.0226(8)$ & $0.0183(7)$ & $0.0183(7)$ & $-0.0005(6)$ & $-0.0024(6)$ & $-0.0094(6)$ \\
C2 & $0.0219(8)$ & $0.0205(8)$ & $0.0234(8)$ & $0.0005(6)$ & $-0.0030(6)$ & $-0.0121(6)$ \\
C3 & $0.0247(9)$ & $0.0209(8)$ & $0.0220(8)$ & $0.0002(6)$ & $-0.0033(6)$ & $-0.0098(6)$ \\
C4 & $0.0237(8)$ & $0.0230(8)$ & $0.0222(8)$ & $-0.0018(6)$ & $-0.0022(6)$ & $-0.0113(6)$ \\
C5 & $0.0206(8)$ & $0.0190(7)$ & $0.0210(8)$ & $-0.0014(6)$ & $-0.0024(6)$ & $-0.0062(6)$ \\
C6 & $0.0290(9)$ & $0.0219(8)$ & $0.0264(9)$ & $0.0035(7)$ & $-0.0059(7)$ & $-0.0108(7)$ \\
C7 & $0.0383(10)$ & $0.0246(8)$ & $0.0227(8)$ & $-0.0004(7)$ & $-0.0067(7)$ & $-0.0099(7)$ \\
C8 & $0.0258(9)$ & $0.0293(9)$ & $0.0228(8)$ & $-0.0015(7)$ & $-0.0078(7)$ & $-0.0041(7)$ \\
C9 & $0.0232(9)$ & $0.0322(9)$ & $0.0271(9)$ & $0.0067(7)$ & $-0.0034(7)$ & $-0.0089(7)$ \\
C10 & $0.0249(9)$ & $0.0298(9)$ & $0.0228(8)$ & $0.0037(7)$ & $-0.0011(7)$ & $-0.0117(7)$ \\
C11 & $0.0228(8)$ & $0.0208(8)$ & $0.0222(8)$ & $0.0042(6)$ & $-0.0070(6)$ & $-0.0119(6)$ \\
C12 & $0.0213(8)$ & $0.0172(7)$ & $0.0178(7)$ & $0.0048(6)$ & $-0.0057(6)$ & $-0.0080(6)$ \\
C13 & $0.0199(8)$ & $0.0263(8)$ & $0.0256(8)$ & $-0.0009(6)$ & $-0.0040(6)$ & $-0.0133(7)$ \\
C14 & $0.0208(8)$ & $0.0337(9)$ & $0.0247(8)$ & $0.0026(7)$ & $0.0001(6)$ & $-0.0150(7)$ \\
C15 & $0.0283(9)$ & $0.0227(8)$ & $0.0191(7)$ & $0.0073(7)$ & $-0.0058(6)$ & $-0.0112(6)$ \\
C16 & $0.0317(9)$ & $0.0233(8)$ & $0.0297(9)$ & $-0.0050(7)$ & $0.0008(7)$ & $-0.0151(7)$ \\
C17 & $0.0276(9)$ & $0.0279(9)$ & $0.0275(9)$ & $-0.0050(7)$ & $0.0064(7)$ & $-0.0168(7)$ \\
C18 & $0.0408(11)$ & $0.0339(10)$ & $0.0314(9)$ & $0.0077(8)$ & $-0.0038(8)$ & $-0.0222(8)$ \\
& & & & & & \\
\hline & & & & & & \\
\hline
\end{tabular}

Geometric parameters $\left(\AA,{ }^{\circ}\right)$

\begin{tabular}{llll}
\hline $\mathrm{S} 1-\mathrm{C} 1$ & $1.6752(16)$ & $\mathrm{C} 9-\mathrm{C} 10$ & $1.385(2)$ \\
$\mathrm{S} 2-\mathrm{C} 1$ & $1.7455(16)$ & $\mathrm{C} 9-\mathrm{H} 9$ & 0.9500 \\
$\mathrm{~S} 2-\mathrm{C} 11$ & $1.8233(16)$ & $\mathrm{C} 10-\mathrm{H} 10$ & 0.9500 \\
$\mathrm{~N} 1-\mathrm{C} 1$ & $1.334(2)$ & $\mathrm{C} 11-\mathrm{C} 12$ & $1.513(2)$ \\
$\mathrm{N} 1-\mathrm{N} 2$ & $1.3845(18)$ & $\mathrm{C} 11-\mathrm{H} 11 \mathrm{~A}$ & 0.9900 \\
$\mathrm{~N} 1-\mathrm{H} 1 \mathrm{~N}$ & $0.873(9)$ & $\mathrm{C} 11-\mathrm{H} 11 \mathrm{~B}$ & 0.9900 \\
$\mathrm{~N} 2-\mathrm{C} 2$ & $1.284(2)$ & $\mathrm{C} 12-\mathrm{C} 17$ & $1.390(2)$ \\
$\mathrm{C} 2-\mathrm{C} 3$ & $1.435(2)$ & $\mathrm{C} 12-\mathrm{C} 13$ & $1.389(2)$ \\
$\mathrm{C} 2-\mathrm{H} 2$ & 0.9500 & $\mathrm{C} 13-\mathrm{C} 14$ & $1.392(2)$ \\
$\mathrm{C} 3-\mathrm{C} 4$ & $1.339(2)$ & $\mathrm{C} 13-\mathrm{H} 13$ & 0.9500 \\
$\mathrm{C} 3-\mathrm{H} 3$ & 0.9500 & $\mathrm{C} 14-\mathrm{C} 15$ & $1.383(2)$ \\
$\mathrm{C} 4-\mathrm{C} 5$ & $1.463(2)$ & $\mathrm{C} 14-\mathrm{H} 14$ & 0.9500 \\
$\mathrm{C} 4-\mathrm{H} 4$ & 0.9500 & $\mathrm{C} 15-\mathrm{C} 16$ & $1.393(2)$ \\
$\mathrm{C} 5-\mathrm{C} 10$ & $1.398(2)$ & $\mathrm{C} 15-\mathrm{C} 18$ & $1.510(2)$ \\
$\mathrm{C} 5-\mathrm{C} 6$ & $1.402(2)$ & $\mathrm{C} 16-\mathrm{C} 17$ & $1.384(2)$ \\
$\mathrm{C} 6-\mathrm{C} 7$ & $1.386(2)$ & $\mathrm{C} 16-\mathrm{H} 16$ & 0.9500
\end{tabular}




\begin{tabular}{|c|c|c|c|}
\hline $\mathrm{C} 6-\mathrm{H} 6$ & 0.9500 & $\mathrm{C} 17-\mathrm{H} 17$ & 0.9500 \\
\hline $\mathrm{C} 7-\mathrm{C} 8$ & $1.390(3)$ & $\mathrm{C} 18-\mathrm{H} 18 \mathrm{~A}$ & 0.9800 \\
\hline $\mathrm{C} 7-\mathrm{H} 7$ & 0.9500 & $\mathrm{C} 18-\mathrm{H} 18 \mathrm{~B}$ & 0.9800 \\
\hline $\mathrm{C} 8-\mathrm{C} 9$ & $1.386(3)$ & $\mathrm{C} 18-\mathrm{H} 18 \mathrm{C}$ & 0.9800 \\
\hline $\mathrm{C} 8-\mathrm{H} 8$ & 0.9500 & & \\
\hline $\mathrm{C} 1-\mathrm{S} 2-\mathrm{C} 11$ & $103.44(7)$ & $\mathrm{C} 9-\mathrm{C} 10-\mathrm{H} 10$ & 119.5 \\
\hline $\mathrm{C} 1-\mathrm{N} 1-\mathrm{N} 2$ & $120.95(13)$ & $\mathrm{C} 5-\mathrm{C} 10-\mathrm{H} 10$ & 119.5 \\
\hline $\mathrm{C} 1-\mathrm{N} 1-\mathrm{H} 1 \mathrm{~N}$ & $118.5(13)$ & $\mathrm{C} 12-\mathrm{C} 11-\mathrm{S} 2$ & $104.86(10)$ \\
\hline $\mathrm{N} 2-\mathrm{N} 1-\mathrm{H} 1 \mathrm{~N}$ & $119.9(13)$ & $\mathrm{C} 12-\mathrm{C} 11-\mathrm{H} 11 \mathrm{~A}$ & 110.8 \\
\hline $\mathrm{C} 2-\mathrm{N} 2-\mathrm{N} 1$ & $114.17(13)$ & $\mathrm{S} 2-\mathrm{C} 11-\mathrm{H} 11 \mathrm{~A}$ & 110.8 \\
\hline $\mathrm{N} 1-\mathrm{C} 1-\mathrm{S} 1$ & $121.06(12)$ & $\mathrm{C} 12-\mathrm{C} 11-\mathrm{H} 11 \mathrm{~B}$ & 110.8 \\
\hline $\mathrm{N} 1-\mathrm{C} 1-\mathrm{S} 2$ & $113.74(11)$ & $\mathrm{S} 2-\mathrm{C} 11-\mathrm{H} 11 \mathrm{~B}$ & 110.8 \\
\hline $\mathrm{S} 1-\mathrm{C} 1-\mathrm{S} 2$ & $125.20(10)$ & $\mathrm{H} 11 \mathrm{~A}-\mathrm{C} 11-\mathrm{H} 11 \mathrm{~B}$ & 108.9 \\
\hline $\mathrm{N} 2-\mathrm{C} 2-\mathrm{C} 3$ & $121.60(15)$ & $\mathrm{C} 17-\mathrm{C} 12-\mathrm{C} 13$ & $118.22(15)$ \\
\hline $\mathrm{N} 2-\mathrm{C} 2-\mathrm{H} 2$ & 119.2 & $\mathrm{C} 17-\mathrm{C} 12-\mathrm{C} 11$ & $121.22(14)$ \\
\hline $\mathrm{C} 3-\mathrm{C} 2-\mathrm{H} 2$ & 119.2 & $\mathrm{C} 13-\mathrm{C} 12-\mathrm{C} 11$ & $120.52(14)$ \\
\hline $\mathrm{C} 4-\mathrm{C} 3-\mathrm{C} 2$ & $121.28(15)$ & $\mathrm{C} 12-\mathrm{C} 13-\mathrm{C} 14$ & $120.52(15)$ \\
\hline $\mathrm{C} 4-\mathrm{C} 3-\mathrm{H} 3$ & 119.4 & $\mathrm{C} 12-\mathrm{C} 13-\mathrm{H} 13$ & 119.7 \\
\hline $\mathrm{C} 2-\mathrm{C} 3-\mathrm{H} 3$ & 119.4 & $\mathrm{C} 14-\mathrm{C} 13-\mathrm{H} 13$ & 119.7 \\
\hline $\mathrm{C} 3-\mathrm{C} 4-\mathrm{C} 5$ & $127.33(16)$ & $\mathrm{C} 15-\mathrm{C} 14-\mathrm{C} 13$ & $121.22(15)$ \\
\hline $\mathrm{C} 3-\mathrm{C} 4-\mathrm{H} 4$ & 116.3 & $\mathrm{C} 15-\mathrm{C} 14-\mathrm{H} 14$ & 119.4 \\
\hline $\mathrm{C} 5-\mathrm{C} 4-\mathrm{H} 4$ & 116.3 & $\mathrm{C} 13-\mathrm{C} 14-\mathrm{H} 14$ & 119.4 \\
\hline $\mathrm{C} 10-\mathrm{C} 5-\mathrm{C} 6$ & $118.13(15)$ & $\mathrm{C} 14-\mathrm{C} 15-\mathrm{C} 16$ & $118.22(15)$ \\
\hline $\mathrm{C} 10-\mathrm{C} 5-\mathrm{C} 4$ & $119.07(15)$ & $\mathrm{C} 14-\mathrm{C} 15-\mathrm{C} 18$ & $121.27(16)$ \\
\hline $\mathrm{C} 6-\mathrm{C} 5-\mathrm{C} 4$ & $122.79(15)$ & $\mathrm{C} 16-\mathrm{C} 15-\mathrm{C} 18$ & $120.51(15)$ \\
\hline $\mathrm{C} 7-\mathrm{C} 6-\mathrm{C} 5$ & $120.63(16)$ & $\mathrm{C} 17-\mathrm{C} 16-\mathrm{C} 15$ & $120.68(16)$ \\
\hline $\mathrm{C} 7-\mathrm{C} 6-\mathrm{H} 6$ & 119.7 & $\mathrm{C} 17-\mathrm{C} 16-\mathrm{H} 16$ & 119.7 \\
\hline $\mathrm{C} 5-\mathrm{C} 6-\mathrm{H} 6$ & 119.7 & $\mathrm{C} 15-\mathrm{C} 16-\mathrm{H} 16$ & 119.7 \\
\hline $\mathrm{C} 6-\mathrm{C} 7-\mathrm{C} 8$ & $120.42(17)$ & $\mathrm{C} 16-\mathrm{C} 17-\mathrm{C} 12$ & $121.16(15)$ \\
\hline $\mathrm{C} 6-\mathrm{C} 7-\mathrm{H} 7$ & 119.8 & $\mathrm{C} 16-\mathrm{C} 17-\mathrm{H} 17$ & 119.4 \\
\hline $\mathrm{C} 8-\mathrm{C} 7-\mathrm{H} 7$ & 119.8 & $\mathrm{C} 12-\mathrm{C} 17-\mathrm{H} 17$ & 119.4 \\
\hline $\mathrm{C} 9-\mathrm{C} 8-\mathrm{C} 7$ & $119.50(16)$ & $\mathrm{C} 15-\mathrm{C} 18-\mathrm{H} 18 \mathrm{~A}$ & 109.5 \\
\hline $\mathrm{C} 9-\mathrm{C} 8-\mathrm{H} 8$ & 120.3 & $\mathrm{C} 15-\mathrm{C} 18-\mathrm{H} 18 \mathrm{~B}$ & 109.5 \\
\hline $\mathrm{C} 7-\mathrm{C} 8-\mathrm{H} 8$ & 120.3 & $\mathrm{H} 18 \mathrm{~A}-\mathrm{C} 18-\mathrm{H} 18 \mathrm{~B}$ & 109.5 \\
\hline $\mathrm{C} 8-\mathrm{C} 9-\mathrm{C} 10$ & $120.21(17)$ & $\mathrm{C} 15-\mathrm{C} 18-\mathrm{H} 18 \mathrm{C}$ & 109.5 \\
\hline $\mathrm{C} 8-\mathrm{C} 9-\mathrm{H} 9$ & 119.9 & $\mathrm{H} 18 \mathrm{~A}-\mathrm{C} 18-\mathrm{H} 18 \mathrm{C}$ & 109.5 \\
\hline $\mathrm{C} 10-\mathrm{C} 9-\mathrm{H} 9$ & 119.9 & $\mathrm{H} 18 \mathrm{~B}-\mathrm{C} 18-\mathrm{H} 18 \mathrm{C}$ & 109.5 \\
\hline $\mathrm{C} 9-\mathrm{C} 10-\mathrm{C} 5$ & $121.09(17)$ & & \\
\hline $\mathrm{C} 1-\mathrm{N} 1-\mathrm{N} 2-\mathrm{C} 2$ & $177.67(14)$ & $\mathrm{C} 6-\mathrm{C} 5-\mathrm{C} 10-\mathrm{C} 9$ & $1.3(2)$ \\
\hline $\mathrm{N} 2-\mathrm{N} 1-\mathrm{C} 1-\mathrm{S} 1$ & $177.67(11)$ & $\mathrm{C} 4-\mathrm{C} 5-\mathrm{C} 10-\mathrm{C} 9$ & $-177.62(15)$ \\
\hline $\mathrm{N} 2-\mathrm{N} 1-\mathrm{C} 1-\mathrm{S} 2$ & $-2.77(19)$ & $\mathrm{C} 1-\mathrm{S} 2-\mathrm{C} 11-\mathrm{C} 12$ & $-179.86(10)$ \\
\hline $\mathrm{C} 11-\mathrm{S} 2-\mathrm{C} 1-\mathrm{N} 1$ & $-178.08(11)$ & $\mathrm{S} 2-\mathrm{C} 11-\mathrm{C} 12-\mathrm{C} 17$ & $-71.41(17)$ \\
\hline $\mathrm{C} 11-\mathrm{S} 2-\mathrm{C} 1-\mathrm{S} 1$ & $1.45(13)$ & $\mathrm{S} 2-\mathrm{C} 11-\mathrm{C} 12-\mathrm{C} 13$ & $106.09(15)$ \\
\hline $\mathrm{N} 1-\mathrm{N} 2-\mathrm{C} 2-\mathrm{C} 3$ & $177.41(13)$ & $\mathrm{C} 17-\mathrm{C} 12-\mathrm{C} 13-\mathrm{C} 14$ & $0.4(2)$ \\
\hline $\mathrm{N} 2-\mathrm{C} 2-\mathrm{C} 3-\mathrm{C} 4$ & $-178.70(15)$ & $\mathrm{C} 11-\mathrm{C} 12-\mathrm{C} 13-\mathrm{C} 14$ & $-177.20(15)$ \\
\hline $\mathrm{C} 2-\mathrm{C} 3-\mathrm{C} 4-\mathrm{C} 5$ & $178.23(15)$ & $\mathrm{C} 12-\mathrm{C} 13-\mathrm{C} 14-\mathrm{C} 15$ & $0.1(3)$ \\
\hline
\end{tabular}




$\begin{array}{llll}\mathrm{C} 3-\mathrm{C} 4-\mathrm{C} 5-\mathrm{C} 10 & 178.69(16) & \mathrm{C} 13-\mathrm{C} 14-\mathrm{C} 15-\mathrm{C} 16 & -0.5(3) \\ \mathrm{C} 3-\mathrm{C} 4-\mathrm{C} 5-\mathrm{C} 6 & -0.2(3) & \mathrm{C} 13-\mathrm{C} 14-\mathrm{C} 15-\mathrm{C} 18 & 179.43(16) \\ \mathrm{C} 10-\mathrm{C} 5-\mathrm{C} 6-\mathrm{C} 7 & -1.7(2) & \mathrm{C} 14-\mathrm{C} 15-\mathrm{C} 16-\mathrm{C} 17 & 0.4(3) \\ \mathrm{C} 4-\mathrm{C} 5-\mathrm{C} 6-\mathrm{C} 7 & 177.21(15) & \mathrm{C} 18-\mathrm{C} 15-\mathrm{C} 16-\mathrm{C} 17 & -179.51(17) \\ \mathrm{C} 5-\mathrm{C} 6-\mathrm{C} 7-\mathrm{C} 8 & 0.9(3) & \mathrm{C} 15-\mathrm{C} 16-\mathrm{C} 17-\mathrm{C} 12 & 0.1(3) \\ \mathrm{C} 6-\mathrm{C} 7-\mathrm{C} 8-\mathrm{C} 9 & 0.3(3) & \mathrm{C} 13-\mathrm{C} 12-\mathrm{C} 17-\mathrm{C} 16 & -0.5(3) \\ \mathrm{C} 7-\mathrm{C} 8-\mathrm{C} 9-\mathrm{C} 10 & -0.7(3) & \mathrm{C} 11-\mathrm{C} 12-\mathrm{C} 17-\mathrm{C} 16 & 177.10(15) \\ \mathrm{C} 8-\mathrm{C} 9-\mathrm{C} 10-\mathrm{C} 5 & -0.2(3) & & \end{array}$

Hydrogen-bond geometry $\left(A,{ }^{\circ}\right)$

$C g 1$ and $C g 2$ are the centroids of the $(\mathrm{C} 5-\mathrm{C} 10)$ and $(\mathrm{C} 12-\mathrm{C} 17)$ rings, respectively.

\begin{tabular}{lllll}
\hline$D-\mathrm{H} \cdots A$ & $D-\mathrm{H}$ & $\mathrm{H} \cdots A$ & $D \cdots A$ & $D-\mathrm{H} \cdots A$ \\
\hline $\mathrm{N} 1-\mathrm{H} 1 N^{\cdots} \cdots \mathrm{S} 1^{\mathrm{i}}$ & $0.87(2)$ & $2.57(2)$ & $3.3984(17)$ & $158(2)$ \\
$\mathrm{C} 14-\mathrm{H} 14 \cdots C g 1^{\mathrm{ii}}$ & 0.95 & 2.95 & $3.6749(19)$ & 134 \\
$\mathrm{C} 8-\mathrm{H} 8 \cdots C g 2^{\mathrm{iii}}$ & 0.95 & 2.75 & $3.5571(19)$ & 143 \\
$\mathrm{C} 11-\mathrm{H} 11 B \cdots C g 2^{\mathrm{iv}}$ & 0.99 & 2.78 & $3.5110(18)$ & 131
\end{tabular}

Symmetry codes: (i) $-x+1,-y+2,-z+1$; (ii) $-x+1,-y+2,-z$; (iii) $-x,-y+2,-z$; (iv) $-x+2,-y+1,-z+1$. 